\title{
Cyber-Physical System: Remote Control Era Revolusi Industri 4.0
}

\section{CHARZON}

165100040

Fakultas Komputer

Charzon.student@umitra.ac.id

\begin{abstract}
Cyber-physical system adalah salah satu aspek dalam cyber-system revolusi industri 4.0. Sistem ini memungkinkan terhubungnya alat yang berbentuk fisik dengan jaringan internet. Bahkan sistem ini pun memungkinkan adanya kontrol dan respons dari internet kepada mesin berbentuk fisik melalui actuator dan senso

Cyber-physical system merujuk pada sistem yang berbentuk fisik, seperti produk yang natural dan alat yang dibuat manusia berbentuk fisik dan dioperasikan dari waktu ke waktu. Alat yang berbentuk fisik menjadi sebuah cyber-physical system karena adanya integrasi dari komputasi, komunikasi, dan kontrol terhadap proses fisik dan adanya feedback dari proses tersebut
\end{abstract}

Kata Kunci : Penerimaan dan Pengeluaran Kas. 
A. PENDAhuluaN

Cyber-physical system merujuk pada sistem yang berbentuk fisik, seperti produk yang natural dan alat yang dibuat manusia berbentuk fisik dan dioperasikan dari waktu ke waktu. Alat yang berbentuk fisik menjadi sebuah cyberphysical system karena adanya integrasi dari komputasi, komunikasi, dan kontrol terhadap proses fisik dan adanya feedback dari proses tersebut

Sistem ini sangat menarik karena menjadi dasar bagi pengembangan berbagai kemampuan dari sebuah produk. Mulai dari desain produk, pembuatan prototype, membuat diagnosis, monitoring, pro aktif dan predictive maintenance, melakukan trackinginformasi, hingga membuat perencanaan dan inovasi. Hal tersebut membuat banyak industri melakukan investasi untuk mengembangkan cyberphysical system untuk industri nya.

\section{B. PEMBAHASAN / STUDI KASUS}

Cyber-physical system dapat digunakan untuk membangun jaringan produksi, kendaraan yang menggunakan remote control, smart home, dan berbagai sistem yang digunakan dengan memanfaatkan jaringan internet, sensor, dan actuator. Cyber-Physical Systemmendapat perhatian dari berbagai industri. Maka dapat dikatakan bahwa berbagai kemampuan tersebut menjadi dasar yang dapat dikembangkan menjadi berbagai layanan cerdas, seperti smart energy, smart services, smart facilities, smart factory, dan lain-lain.

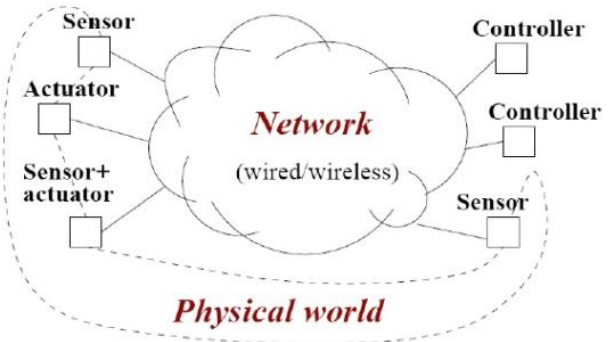

Gambar menunjukkan bagaimana jaringan internet mampu menghubungkan controller, sensor, dan actuator. Terdapat hubungan timbal balik dari jaringan internet ke physical world, dalam hal ini adalah sensor dan actuator. Di jaringan internet terdapat berbagai data yang dapat diidentifikasi, diolah, dan klasifikasikan oleh sensor dan actuator. Selanjutnya melalui controller dapat diberikan perintah pengambilan data, pengolahan data, bahkan penggunaan berbagai data tersebut. Data dalam ini dapat berbagai macam sektor dan tujuannya, baik untuk industri, lembaga sosial, lembaga pemerintah, hingga untuk hiburan.

Dalam pengembangan cyber-physical system terdapat beberapa aspek yang perlu di perhatikan mulai dari 
pengembangan metode, teknologi, serta biaya yang efektif. Negaranegara yang selama ini memiliki industri manufaktur pasti ingin mengembangkan cyber-physical system untuk meningkatkan produktivitasnya, termasuk Indonesia. Maka dalam prosesnya dibutuhkan perhatian dalam hal analisis, desain, memahami interaksi antara sistem kontrol dengan tenaga kerja, jaminan keamanan, stabilitas, dan performa, serta meminimalisir biaya yang akan dibayar oleh konsumen.

Selain itu, dalam konteks Indonesia juga masih dibutuhkan penelitian dan pengembangan terkait cyber-physical system. Menurut Baheti dan

Gill (2011), walaupun cyber-physical system telah berkembang, tetap dibutuhkan penelitian terkait diversifikasi model dan komponen dari cyber-physical system yang tepat. Serta pendekatan yang ideal untuk melakukan perubahan dari penggunaan teknologi biasanya menjadi maksimalisasi cyber-physical system. Kajian yang juga penting untuk dilakukan yaitu mengembangkan alat yang dapat diandalkan dan dapat dikonfigurasi ulang dalam banyak aplikas

\section{ID SECURITY} QWTD4452377-ASP-5244107

\section{KESIMPULAN}

Cyber-physical system merujuk pada sistem yang berbentuk fisik, seperti produk yang natural dan alat yang dibuat manusia berbentuk fisik dan dioperasikan dari waktu ke waktu. Alat yang berbentuk fisik menjadi sebuah cyberphysical system karena adanya integrasi dari komputasi, komunikasi, dan kontrol terhadap proses fisik dan adanya feedback dari proses tersebut

\section{E. DISKUSI}

Cyber-physical system adalah salah satu aspek dalam cybersystem revolusi industri 4.0.

Sistem ini memungkinkan terhubungnya alat yang berbentuk fisik dengan jaringan internet. Bahkan sistem ini pun memungkinkan adanya kontrol dan respons dari internet kepada mesin berbentuk fisik melalui actuator dan sensor negara yang selama ini memiliki industri manufaktur pasti ingin mengembangkan cyberphysical system untuk meningkatkan produktivitasnya, termasuk Indonesia. Maka dalam prosesnya dibutuhkan perhatian dalam hal analisis, desain, memahami interaksi antara sistem kontrol dengan tenaga kerja, jaminan keamanan, stabilitas, dan performa, serta meminimalisir biaya yang akan dibayar oleh konsumen 


\section{F. REFERENCE}

[1] O. M. Febriani and A. S. Putra, "Sistem Informasi Monitoring Inventori Barang Pada Balai Riset Standardisasi Industri Bandar Lampung," J. Inform., vol. 13, no. 1, pp. 90-98, 2014.

[2] A. S. Putra, "Paperplain: Execution Fundamental Create Application With Borland Delphi 7.0 University Of Mitra Indonesia," 2018.

[3] A. S. Putra, "2018 Artikel Struktur Data, Audit Dan Jaringan Komputer," 2018.

A. S. Putra, "ALIAS MANAGER USED IN DATABASE DESKTOP STUDI CASE DB DEMOS." A. S. Putra, "COMPREHENSIVE SET OF PROFESSIONAL FOR DISTRIBUTE COMPUTING."

[6] A. S. Putra, "DATA ORIENTED RECOGNITION IN BORLAND DELPHI 7.0."

[7] A. S. Putra, "EMBARCADERO DELPHI XE 2 IN GPUPOWERED FIREMONKEY APPLICATION."

[8] A. S. Putra, "HAK ATAS KEKAYAAN INTELEKTUAL DALAM DUNIA TEKNOLOGY BERBASIS REVOLUSI INDUSTRI 4.0."

[9] A. S. Putra, "IMPLEMENTASI PERATURAN

PERUNDANGAN UU. NO 31

TAHUN 2000 TENTANG DESAIN INDUSTRI 


\begin{tabular}{|c|c|c|c|}
\hline & INFORMATION & & TECHNOLOGY BASED 4.0.” \\
\hline & TECHNOLOGY." & {$[21]$} & "TOOLBAR \\
\hline \multirow[t]{3}{*}{ [10] } & Putra, & & COMPONENT PALLETTE IN \\
\hline & “IMPLEMENTATION & & ORIENTED \\
\hline & PARADOX DBASE." & & PROGRAMMING.” \\
\hline \multirow[t]{4}{*}{ [11] } & Putra, & {$[22]$} & A. S. Putra, "WORKING \\
\hline & “IMPLEMENTATION & & DIRECTORY \\
\hline & SECRET & & PARADOX 7." \\
\hline & STUDY SAMSUNG MOBILE & {$[23]$} & A. S. Putra, "ZQUERY \\
\hline \multirow{6}{*}[12]{} & $\begin{array}{l}\mathrm{PH} \\
\mathrm{A} .\end{array}$ & & $\begin{array}{l}\text { IMPLEMENTED } \\
\text { IMPINECTION }\end{array}$ \\
\hline & "IMPLEMENTATION & & PROGRAMMING \\
\hline & PATENT FOR APPLICATION & & CASE PT. BANK BCA Tbk.” \\
\hline & WEB BASED CASE STUDI & [24] & A. S. Putra, D. R. Aryanti, and \\
\hline & WWW. PUBLIKLAMPUNG. & & I. Hartati, "Metode SAW \\
\hline & COM." & & (Simple Additive Weighting) \\
\hline \multirow[t]{4}{*}[13]{} & Putra, & & sebagai Sistem \\
\hline & “IMPLEMENTATION & & Keputusan Guru Berprestasi \\
\hline & SYSTEM FIRST TO INVENT & & (Studi Kasus: SMK Global \\
\hline & IN DIGITALLY INDUSTRY.” & & Surya)," in Prosiding Seminar \\
\hline \multirow[t]{5}{*}{ [14] } & A. S. Putra, "MANUAL & & Nasional Darmajaya, 2018, vol. \\
\hline & REPORT \& INTEGRATED & & 1, no. 1 , pp. 85-97. \\
\hline & DEVELOPMENT & {$[25]$} & A. S. Putra and O. M. Febriani, \\
\hline & ENVIRONMENT BORLAND & & Management \\
\hline & DELPHI 7.0.” & & Online Application in PDAM \\
\hline \multirow[t]{3}{*}[15]{} & A. S. Putra, "PATENT AS & & Lampung Province," in \\
\hline & RELEVAN & & International \\
\hline & RESEARCH.” & & Information \\
\hline \multirow[t]{3}{*}{ [16] } & A. S. Putra, "PATENT FOR & & Technology and Business \\
\hline & RESEARCH STUDY CASE & & (ICITB), 2018, pp. 181-187. \\
\hline & OF APPLE. Inc." & {$[26]$} & A. S. Putra, O. M. Febriani, and \\
\hline \multirow[t]{3}{*}{ [17] } & A. S. Putra, & & "Implementasi \\
\hline & PROTECTION & & Genetic Fuzzy System Untuk \\
\hline & APPLICATION INVENT." & & Mengidentifikasi Hasil Curian \\
\hline \multirow[t]{3}{*}{ [18] } & A. S. Putra, "QUICK REPORT & & Kendaraan Bermotor Di Polda \\
\hline & PROPERTY & & Lampung," SIMADA (Jurnal \\
\hline & PROGRAMMING." & & Sist. Inf. dan Manaj. Basis \\
\hline \multirow[t]{4}{*}{ [19] } & $\begin{array}{lll}\text { A. S. } & \text { Putra, } & \text { "REVIEW } \\
\text { CIRCUIT } & & \text { LAYOUT }\end{array}$ & & $\begin{array}{l}\text { Data), vol. } 1 \text {, no. } 1 \text {, pp. } 21-30 \text {, } \\
2018 .\end{array}$ \\
\hline & COMPONENT & {$[27]$} & A. S. Putra, H. Sukri, and K. \\
\hline & REQUIREMENT ON ASUS & & Zuhri, "Sistem Monitoring \\
\hline & NOTEBOOK." & & Realtime Jaringan Irigasi Desa \\
\hline \multirow[t]{3}{*}{ [20] } & A. S. Putra, "REVIEW & & (JIDES) \\
\hline & TRADEMARK PATENT FOR & & Jaringan Sensor Nirkabel," \\
\hline & INDUS & & IJEIS (Indonesian J. Electron. \\
\hline
\end{tabular}


Instrum. Syst., vol. 8, no. 2, pp. 221-232.

[28] D. P. Sari, O. M. Febriani, and A. S. Putra, "Perancangan Sistem Informasi SDM Berprestasi pada SD Global Surya," in Prosiding Seminar Nasional Darmajaya, 2018, vol. 1, no. 1, pp. 289-294. 